\title{
PENGARUH KEGIATAN EKSTRAKURIKULER DAN MOTIVASI BELAJAR TERHADAP PRESTASI BELAJAR SISWA
}

\author{
Ani Nofianti \\ Manajemen Pendidikan Universitas Negeri Surabaya \\ aninofianti69@yahoo.com
}

\begin{abstract}
This study aims to determine the effect of extracurricular activities on student achievement in Senior High School 1 Prambon Nganjuk. This study uses a quantitative approach, there are three variables, namely extracurricular activities (X1), learning motivation (X2) and learning achievement $(Y)$. The population in this study were students of class XI Senior High School 1 Prambon Nganjuk as many as 281 students with a sample of 165 students. This research method uses a quantitative research approach with a type of research correlation with causal forms. The sampling technique in this study was using simple random sampling technique. Data collection techniques in the form of questionnaires or questionnaires using a Likert scale and documentation. Test requirements for research data analysis using normality test and linearity test. The data analysis technique uses multiple regression analysis because this study uses two or more independent variables, analysis of the T Test to answer hypotheses one and two and Test $F$ to answer the third hypothesis. Data was analyzed using the SPSS 21.0 program. Based on the results of data analysis on the $T$ test the extracurricular activity variables partially influence the learning achievement variables of 0,021 , and the learning motivation variables partially influence the teacher performance variable by 0,010 . in the $F$ test shows the calculated $F$ value of 5,493 . The significant value of extracurricular activity variables and learning motivation towards learning achievement obtained is 0,005 . This significant value is smaller than the alpha value of 0,05 , so $\mathrm{HO}$ is rejected and $\mathrm{H} 1$ is accepted, meaning extracurricular activities and motivation to learn together affect the student achievement of Prambon Nganjuk 1 High School. The magnitude of the influence of work motivation and organizational culture on teacher performance is $6,4 \%$.
\end{abstract}

Keywords: Extracurricular Activities, Learning Motivation, Learning Achievement

\begin{abstract}
Abstrak: Penelitian ini bertujuan untuk mengetahui pengaruh kegiatan ekstrakurikuler terhadap prestasi belajar siswa di SMA Negeri 1 Prambon Nganjuk. Penelitian ini menggunakan pendekatan kuantitatif, terdapat tiga variabel yaitu kegiatan ekstrakurikuler $\left(\mathrm{X}_{1}\right)$, motivasi belajar $\left(\mathrm{X}_{2}\right)$ dan prestasi belajar $(\mathrm{Y})$. Populasi dalam penelitian ini adalah siswa kelas XI SMA Negeri 1 Prambon Nganjuk sebanyak 281 siswa dengan sampel sebanyak 165 siswa. Metode penelitian ini menggunakan pendekatan penelitian kuantitatif dengan jenis penelitian korelasi dengan bentuk kausal. Teknik pengambilan sampel dalam penelitian ini adalah menggunakan teknik simple random sampling. Teknik pengumpulan data berupa angket atau kuisioner dengan menggunakan skala likert dan dokumentasi. Uji persyaratan analisis data penelitian menggunakan uji normalitas dan uji linieritas. Teknik analisis data menggunakan analisis regresi ganda karena penelitian ini mengguanakan dua atau lebih variabel independen, analisis Uji T untuk menjawab hipotesis satu dan dua serta Uji F untuk menjawab hipotesis ketiga. Data di analisis menggunakan program SPSS 21.0. Berdasarkan hasil analisis data pada uji $\mathrm{T}$ variabel kegiatan ekstrakurikuler secara parsial berpengaruh terhadap variabel prestasi belajar sebesar 0,021 , serta variabel motivasi belajar secara parsial berpengaruh terhadap variabel kinerja guru sebesar 0,010 . pada uji $F$ menunjukkan nilai $F_{\text {hitung }}$ sebesar 5,493. Nilai signifikan variabel kegiatan ekstrakurikuler dan motivasi belajar terhadap prestasi belajar yang diperoleh adalah sebesar 0,005 . Nilai signifikan ini lebih kecil dari nilai alpha yaitu 0,05 dengan demikian $\mathrm{H}_{0}$ ditolak dan $\mathrm{H}_{1}$ diterima, artinya kegiatan ekstrakurikuler dan motivasi belajar secara bersama-sama berpengaruh terhadap prestasi belajar siswa SMA Negeri 1 Prambon Nganjuk. Adapun besarnya pengaruh motivasi kerja dan budaya organisasi terhadap kinerja guru yaitu sebesar $6,4 \%$.
\end{abstract}

Kata kunci: kegiatan ekstrakurikuler, motivasi belajar, prestasi belajar 
Prestasi belajar merupakan salah satu hal penting dalam pendidikan di seluruh sekolah yang ada di dunia, termasuk Indonesia. (Emda, 2018) belajar merupakan kegiatan pokok dalam proses pendidikan di sekolah. Belajar adalah usaha yang dilakukan secara sadar untuk merubah sikap dan tingkah lakunya. (winkel, 2004)bahwa dalam rangka evaluasi produk, pengukuran tentang prestasi yang diberikan oleh seorang siswa memegang peranan penting. Dalam pengukurannya, biasanya digunakan ukuran-ukuran tertentu dan angka-angka. (Arumsari, 2017)mengemukakan bahwa prestasi belajar siswa tersebut dinilai dari beberapa aspek dan kriteria penilaian tertentu, misalnya dari aspek kognitif, aspek afektif maupun dari aspek psikomotornya

Berdasarkan data yang ada di lapangan peneliti memperoleh data hasil ujian nasional yang di capai oleh peserta didik SMA Negeri 1 Prambon Nganjuk selama tiga tahun terakhir dengan perolehan hasil rata-rata pada setiap mata pelajaran yang diujikan mengalami naik turun setiap tahunnnya, hampir pada semua mata pelajaran yang diujikan. Adapun tabel perolehan rata-rata nilai ujian nasional peserta didik SMA Negeri 1 Prambon Nganjuk dalam tiga tahun terakhir sebagai berikut:

Tabel 1. Data Lapangan rata-rata nilai Ujian Nasional

\begin{tabular}{cccc}
\hline \multirow{2}{*}{ Jurusan } & \multicolumn{3}{c}{ Tahun Ajaran } \\
& $\mathbf{2 0 1 5 / 2 0 1 6}$ & $\mathbf{2 0 1 6 / 2 0 1 7}$ & $\mathbf{2 0 1 7 / 2 0 1 8}$ \\
\hline IPA & 53,74 & 44,20 & 50,26 \\
IPS & 60,08 & 51,81 & 53,32 \\
\hline
\end{tabular}

Sumber: http://puspendik.kemdikbud.go.id/

Hasil ujian nasional yang diperoleh tersebut menunjukkan terjadi naik turun pada setiap mata pelajaran IPA maupun IPS sehingga dalam pengambilan hasil nilai ratarata juga mengalami naik turun. Dalam hal ini dapat berpengaruh pada faktor kelulusan peserta didik. Walaupun tidak semua nilai kelulusan di tentukan oleh nilai UN, namun nilai UN ini yang kemudian akan menjadi setengah nilai penentu dari hasil penggabungan dari nilai sekolah sehingga dapat diketahui nilai akhir yang diperoleh oleh peserta didik. Dapat di simpulkan bahwa dari data rata-rata nilai ujian nasional yang diperoleh peserta didik tingkat SMA/SMK/MA di Jawa Timur yang mengalami penurunan dengan data rata-rata nilai ujian nasional di lapangan yang terjadi naik turun. Hal ini harus segera diatasi agar dapat memenuhi tujuan dari pendidikan nasional untuk berprestasi lebih baik.

Prestasi belajar yang kurang optimal menjadi permasalahan pendidikan dalam mencapai keberhasilan suatu pendidikan tersebut. Menurut (Subkhan \& Setiyani, 2015)Prestasi belajar sangatlah penting, hasil yang dicapai setelah siswa melakukan dan mengerjakan proses pembelajaran dapat dilihat dari prestasi belajar.

Melalui kegiatan ekstrakurikuler yang ada disetiap sekolah diharapkan dapat mempengaruhi prestasi belajar yang diperoleh oleh peserta didik. Selain peserta didik, guru juga dapat ikut serta membina peserta didiknya melalui kegiatan ekstrakurikuler. Menurut (Abu \& Widodo, 2004) berpendapat bahwa dalam hakikat belajar mengajar dapat terjadi dengan adanya keaktifan individu atau siswa tersebut selama proses belajar mengajar. Sehingga dengan cara belajar siswa yang aktif ini akan menjadikan proses kegiatan belajar mengajar yang subjek didiknya terlibat secara emosional dan intelektual, sehingga subjek didik benar-benar berperan dan berpartisipasi aktif dalam melakukan kegiatan belajar. Menurut (Melvin, 2016) kegiatan belajar aktif menyita lebih banyak waktu ketimbang pengajaran langsung, namun ada banyak cara untuk menghindari terbuangnya waktu yang sia-sia. Pendidikan di segala jenjang pada umunya dimaksudkan untuk mendapatkan pengetahuan, keterampilan, dan sikap.

Salah satu strategi belajar mengajar yang menuntut keaktifan dan partisipasi subjek didik seoptimal mungkin ini dapat melalui kegiatan ekstrakurikuler yang dilaksanakan dalam masing-masing lembaga pendidikan. Menurut (Nuryanto, 2017)Kegiatan ekstrakurikuler dalam pendidikan dimaksudkan sebagai jawaban atas tuntutan kebutuhan peserta didik, membantu mereka yang kurang, memperkaya lingkungan belajar dan menstimulasi mereka agar lebih kreatif. Sehingga siswa mampu mengubah tingkah lakunya secara lebih efektif dan efisien maupun dalam pengembangan potensi, minat dan bakat yang dimiliki oleh masingmasing individu atau siswa tersebut untuk 
memperoleh tujuan pembelajaran seoptimal mungkin.

Keterkaitan antara kurikuler, kokurikuler, dan ekstrakurikuler ini adalah kokurikuler merupakan kegiatan diluar dari kurikuler, kegiatan ini menunjang dan mendukung kurikuler maupun ekstrakurikuler karena pada proses pembelajaran guru memberikan kegiatan kokurikuler di luar jam kurikuler dan ekstrakurikuler yang bertujuan untuk menciptakan pemahaman yang mendasar dan wadah pengembangan potensi, bakat, minat peserta didik serta menciptakan interaksi pemahaman di luar jam sekolah dalam mencapai prestasi belajar yang lebih baik.

Menurut (Lestari, 2016) Ekstrakurikuler merupakan suatu kegiatan pendidikan yang dilakukan di sekolah yang dilakukan di luar kelas. Terdapat 24 kegiatan ekstrakurikuler di SMA Negeri 1 Prambon Nganjuk, 2 diantara banyaknya ekstrakurikuler tersebut bersifat wajib dan yang lainnya pilihan untuk diikuti peserta didik, yaitu ekstrakurikuler pramuka yang di wajibkan di kelas $X$, ekstrakurikuler keagamaan (majelis taklim) yang diwajibkan di kelas XI, Palang Merah Remaja (PMR), Karya IImiah Remaja (KIR), mading, bola volly, sepak bola, bulu tangkis, bola basket, musik band, hadrah, English Club (EC), theater and mading, jurnalistik, paskibraka, tari, OSN biologi, OSN fisika, OSN matematika, OSN kebumian, OSN astronomi, OSN geografi, OSN TIK, dan OSN ekonomi.

Berdasarkan pendapat (Melvin, 2016) siswa dapat melaksanakannya kegiatan ekstrakurikuler ini dengan baik. Agar tercapai tujuan yang diharapkan untuk peserta didik. Sehingga siswa dapat melaksankannya sebaik mungkin, maka siswa harus aktif dalam mengikuti kegiatan ekstrakurikuler yang ada di sekolah. Sebagai acuan pengukuran untuk mengetahui siswa aktif dalam megikuti kegiatan ekstrakurikuler, dapat digunakan indikator sebagai berikut, yaitu : (1) keinginan dan keterlibatan untuk berpartisipasi dalam kegiatan ekstrakurikuler, (2) usaha konstribusi dalam kegiatan ekstrakurikuler, (3) tanggung jawab untuk mencapai prestasi dalam kegiatan ekstrakurikuler, (4) kemandirian dalam kegiatan ekstrakurikuler.
Motivasi belajar merupakan dorongan melakukan sesuatu yang berasal dari dalam diri seseorang dan luar diri seseorang tersebut. Menurut (Prawira \& Atmaja, 2012) Motivasi yang berasal dari luar diri individu diberikan oleh motivator seperti orang tuanya, guru, konselor, ustadz/ustadzah, orang dekat atau teman dekat, dan lain-lain. Sedangkan motivasi yang berasal atau timbul dalam diri seseorang, dapat disebabkan seseorang mempunyai keinginan untuk dapat menggapai sesuatu (cita-cita) dan lain sebagainya. (Sidik \& Sobandi, 2018)berpendapat bahwa Perlunya motivasi dalam kegiatan pembelajaran untuk mendorong kemauan dan daya penggerak pada siswa akan kebutuhan belajar. Menurut (Rozaini \& Anti, 2017)Motivasi belajar merupakan salah satu faktor yang mempengaruhi keberprestasian siswa dalam melakukan kegiatan belajarnya.Semakin tinggi motivasi dalam diri siswa tentunya berdampak pada efektifitas dan efesiensi belajarnya.

Motivasi belajar peserta didik SMA Negeri 1 Prambon Nganjuk dapat dikatakan cukup baik. Walaupun masih terdapat beberapa siswa yang kurang disiplin di sekolah. Terdapat kendala dalam motivasi belajar siswa adalah pada moral peserta didik tersebut. Berhubungan dengan kepribadian dan asal siswa tersebut berasal atau berada. Pengaruh dari lingkungan, keluarga, dan masyarakat yang baik maka moral anak tersebut akan baik, begitu sebaliknya. Menurut Woolfolk (2009:226) motivasi adalah keadaan internal yang membangkitkan, mengarahkan, dan mempertahankan perilaku, motivasi siswa untuk belajar adalah trait dan juga state. Motivasi itu melibatkan anggapan serius tugas akademik, berusaha mendapatkan sebanyak mungkin darinya, dan menerapkan strategi belajar yang tepat-guna dalam prosesnya. (Syamsuddin Makmun, 2007)berpendapat motivasi merupakan suatu tenaga (forces) atau kekuatan (power) atau daya (energy), suatu keadaan yang kompleks (a complex state) dan kesiapsediaan (preparatory set) dalam diri individu (organisme) untuk bergerak (to move, motion, motive) ke arah tujuan tertentu, baik disadari maupun tidak disadari. Timbulnya motivasi tersebut tumbuh dan 
berkembang dengan jalan datang dari dalam diri individu itu sendiri (intrinsik) dan datang dari lingkungan (ekstrinsik). Dalam hal ini, motivasi belajar dapat diukur dan ditingkatkan melalui beberapa indikatornya dalam term-term tertentu.

Sehingga dari pendapat Woolfolk (2009:226) di atas dijelaskan bahwa dalam hal pemahaman motivasi setiap individu sebagai acuan pengukuran motivasi belajar siswa di sekolah dapat melalui beberapa indikator, yaitu: (1) durasi pada kegiatan, yaitu penggunaan berapa lama waktu pada kemampuan seseorang untuk melaksanakan suatu kegiatan, (2) frekuensi pada kegiatan, yakni periode waktu tertentu yang sering dilakukan dalam kegiatan,

persistensinya, tujuan terhadap kegiatan pada arah kelekatan dan ketetapannya, (4) dalam menghadapi rintangan dan kesulitan diperlukan keuletan, kemampuan, dan ketabahan untuk mencapai tujuan, (5) pengabdian atau devosi dan pengorbanan, yakni pikiran, uang, tenaga, bahkan nyawa atau jiwanya untuk mencapai tujuan, (6) tingkat aspirasi, yakni maksud, rencana, citacita, sasaran atau target, dan idolanya yang hendak dicapai dengan kegiatan yang dilakukan, (7) tingkat kualifikasi produk atau out put atau prestasi, yakni memadai atau tidak, memuaskan atau tidak, dan seberapa banyak pencapaian kegiatan tersebut, (8) arah terhadap sikap, yakni like or dislike, positif atau negatif terhadap sasaran kegiatan.

Berdasarkan uraian tersebut maka peneliti tertarik untuk melakukan penelitian dengan judul "Pengaruh Kegiatan Ekstrakurikuler dan Motivasi Belajar Terhadap Prestasi Belajar Siswa SMA Negeri 1 Prambon Nganjuk".

\section{METODE}

Penelitian ini menggunakan penelitian kuantitatif yang menggunakan rumusan masalah asosiatif dengan hubungan kausal. Menurut (sugiyono, 2017) Rumusan masalah assosiatif merupakan rumusan masalah penelitian yang bersifat menanyakan hubungan antara dua variabel atau lebih. Sedangkan yang dimaksud dengan hubungan yang bersifat sebab akibat yang terdapat variabel independen $(\mathrm{X})$, yakni variabel yang mempengaruhi dan variabel dependen $(\mathrm{Y})$ yaitu variabel yang dipengaruhi.

Penelitian ini mengukur sejauh mana pengaruh kegiatan ekstrakurikuler dan motivasi belajar terhadap prestasi belajar siswa yang dapat dipahami pada gambar 1 sebagai berikut:

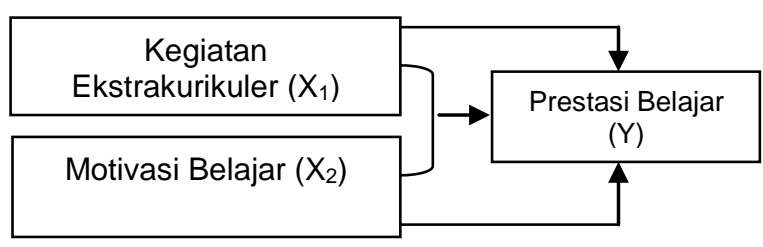

Gambar 1 Rancangan Penelitian

Populasi dalam penelitian ini menggunakan jenis populasi seluruh siswa kelas XI di SMA Negeri 1 Prambon Nganjuk tahun ajaran 2018-2019 dengan jumlah 281 siswa. Jumlah responden dalam peneltian ini cukup besar, maka diambil sebagian untuk dijadikan sebagai sampel penelitian yaitu 165 siswa.

Berdasarkan rumus Slovin dalam pengambilan sampel penelitian didapatkan hasil 165 siswa sebagai sampel penelitian dari jumlah populasi sebanyak 281 siswa kelas XI di SMA Negeri 1 Prambon Nganjuk tahun ajaran 2018-2019. Teknik pengumpulan data dalam penelitian ini menggunakan wawancara sebagai studi pendahuluan, angket atau kuisioner, dan dokumetasi menggunakan studi pendahuluan dan nilai rapot siswa.

Pengembangan instrumen yang dilakukan peneliti yaitu dengan pengadaan uji validitas dan reliabilitas dengan bantuan program SPSS 21.0 for windows. Uji validitas dan reliabilitas pada penelitian ini dilakukan dengan melakukan penyebaran skala peneltian 30 responden di kelas XI di SMA Negeri 1 Prambon Nganjuk. Uji validitas menggunakan rumus korelasi Product Momen, dengan catatan nilai $r_{\text {tabel }}$ yang telah ditentukan pada taraf $5 \%$ yakni 0,361 maka item dikatakan valid jika $r_{\text {hitung }}$ lebih besar $r_{\text {tabel. }}$. sedangkan uji reliabilitas menggunakan rumus Alpha Cronbach, dengan catatan intrumen dikatakan reliabel jika $>0,6$. Setelah dilakukan uji coba angket pada 30 responden, jumlah soal valid dan reliabel sebanyak 47 butir dengan incian 18 butir pada variabel kegiatan ekstrakurikuler dan 29 butir pada variabel motivasi belajar, 
sehingga skala penelitian dapat digunakan untuk penelitian.

Teknik analisis data yang digunakan dalam penelitian ini menggunakan analisis regresi ganda. Sebelum menghitung regresi ganda terdapat beberapa persyatratan dalam analisis data yang harus dipenuhi antara lain, uji persyaratan analisis data yang meliputi uji normalitas dan uji linieritas. untuk analisis data menggunakan analisis regresi ganda, analisis uji $\mathrm{T}$ (pengaruh secara parsial) dan analisis uji $F$ (pengaruh secara simultan)

\section{HASIL DAN PEMBAHASAN \\ Pengaruh Kegiatan Ekstrakurikuler Terhadap Prestasi Belajar Siswa di SMA Negeri 1 Prambon Nganjuk}

Penelitian tentang pengaruh kegiatan ekstrakurikuler terhadap prestasi belajar siswa di SMA Negeri 1 Prambon Nganjuk ini diperoleh hipotesis, yaitu kegiatan ekstrakurikuler secara parsial berpengaruh terhadap prestasi belajar siswa di SMA Negeri 1 Prambon Nganjuk. Hasil pengujian linieritas diketahui bahwa hasil perhitungan taraf signifikansi untuk variabel kegiatan ekstrakurikuler dan prestasi beajar adalah 0,582 yang artinya (deviation from linearity) adalah $0,582>0,05$, sehingga dapat disimpulkan kedua variabel mempunyai hubungan yang linier. Nilai 0,051 $X_{1}$ merupakan koefisien regresi yang menunjukkan bahwa jika nilai variabel kegiatan ekstrakurikuler $\left(X_{1}\right)$ ditingkatkan sebesar satu satuan akan menyebabkan peningkatan nilai dari variabel terikat yaitu prestasi belajar (Y) sebesar 0,051 satuan.

Hasil uji parsial (uji $T$ ) pengaruh kegiatan ekstrakurikuler $\left(\mathrm{X}_{1}\right)$ terhadap prestasi belajar $(\mathrm{Y})$, maka berdasarkan hasil perhitungan koefisien regresi dengan uji $T$ diperoleh $T_{\text {hitung }}$ sebesar 2,339. Nilai $T_{\text {hitung }}$ ini lebih besar dari $\mathrm{T}_{\text {tabel }}$ yakni sebesar 1,97472. Sedangkan nilai signifikan yang diperoleh adalah sebesar 0,021. Nilai signifikan ini lebih kecil dari nilai alpha 0,05 dengan demikian $\mathrm{H}_{0}$ ditolak dan $\mathrm{H}_{1}$ diterima, artinya kegiatan ekstrakurikuler berpengaruh secara signifikan terhadap prestasi belajar siswa di SMA Negeri 1 Prambon Nganjuk. Hal tersebut dapat diketahui nilai signifikan ( $\mathrm{sig}$ ) kegiatan ekstrakurikuler $\left(X_{1}\right)$ yaitu 0,021 yang lebih kecil dari nilai alpha 0,05 yang artinya $\mathrm{H}_{0}$ ditolak dan $\mathrm{H}_{1}$ diterima, dari hasil tersebut dinyatakan bahwa kegiatan ekstrakurikuler berpengaruh terhadap prestasi belajar dan dapat dilihat dari tanggapan responden yang memberikan nilai positif pada jawaban dalam instrumen, sehingga dapat disimpulkan bahwa kegiatan ekstrakurikuler dalam hal ini adalah ekstrakurikuler keagamaan yaitu majelis taklim dapat diterima dengan baik oleh siswa di SMA Negeri 1 Prambon Nganjuk.

Hal ini didasarkan pada hasil penelitian variabel kegiatan ekstrakurikuler $\left(\mathrm{X}_{1}\right)$ dengan 165 responden yang dapat disimpulkan bahwa sebagian besar responden menganggap kegiatan ekstrakurikuler di SMA Negeri 1 Prambon Nganjuk sangat baik karena responden cenderung memilih angka 3 dan 4 dengan jumlah $91,7 \%$ dan variabel prestasi belajar siswa yang diperoleh dari nilai rapor siswa kelas XI. Untuk mengetahui prestasi belajar yang diperoleh siswa kelas XI dilakukan rata-rata dari nilai pengetahuan dan keterampilan siswa dari seluruh mata pelajarannya yang ditempuh.

Hasil penelitian dari kegiatan ekstrakurikuler siswa di SMA Negeri 1 Prambon Nganjuk sejalan dengan tujuan pelaksanaan ektrakurikuler di sekolah menurut (Pendidikan \& Nomor, 62AD) bahwa kegiatan ekstrakurikuler dilaksanakan dengan tujuan untuk mengembangkan bakat, potensi, minat, kerjasama, kemandirian, kemampuan, dan kepribadian peserta didik secara optimal untuk mendukung ketercapaian tujuan dari pendidikan nasional. Tujuan tersebut menjelaskan bahwa melalui bakat, potensi, minat, kerjasama, kemandirian, kemampuan, dan kepribadian yang dimiliki peserta didik dapat mendorong untuk lebih meningkatkan prestasi belajarnya secara optimal. Sehingga dengan dilaksanakan kegiatan ekstrakurikuler dengan tujuan tersebut dapat mempengaruhi dan meningkatkan semangat siswa dalam mencapai prestasi belajar yang sesuia dengan tujuan dari pendidikan nasional.

Kegiatan ekstrakurikuler disediakan oleh sekolah sebagai wadah untuk siswa dapat mengembangkan kompetensinya dibidang non-akademik. Terdapat 24 kegiatan ekstrakurikuler yang dilaksanakan di SMA Negeri 1 Prambon Nganjuk, 2 diantara 
banyaknya ekstrakurikuler tersebut bersifat wajib dan yang lainnya pilihan untuk diikuti peserta didik. Hasil penelitian ini juga sejalan dengan kegiatan ekstrakurikuler menurut (Prihatin, 2011)dapat meliputi kegiatan keagamaan, olahraga, sosial dan budaya, berorganisasi, wirausaha, dan kegiatan sosial lainnya. Kegiatan ekstrakurikuler ini dapat ikut andil dalam meningkatkan prestasi belajar peserta didik. Peneliti dalam hal ini lebih memfokuskan kegiatan ekstrakurikuler ini pada kegiatan ekstrakurikuler keagamaan (majelis taklim). Adanya ekstrakurikuler ini selain untuk mendukung visi-misi SMA Negeri 1 Prambon juga merupakan salah satu dari ekstrakurikuler yang menjadi suatu kegiatan yang berbasiskan agama dan diwajibkan.

Terdapat program kegiatan yang diusahakan dapat menciptakan, membangun sikap dan keinginan dari dalam diri siswa untuk aktif mengikuti dan meningkatkan prestasi belajar dan mengembangkan potensi diri peserta didik melalui ekstrakurikuler ini. Harapan atau output siswa dapat mengerti dan dapat mengaji, memiliki bekal ilmu keagamaan, berakhlaq yang baik, dan sebagainya. Sehingga siswa dalam hal ini dapat membentengi dirinya untuk melakukan sesuatu dalam kehidupan sehari-hari. Termasuk dalam hal kegiatan belajar mengajar disekolah. Kegiatan ekstrakurikuer ini dapat mendorong siswa untuk melakukan hal positif dalam hal mengembangkan bakat, minat, potensi, serta kemampuan yang dimiliki oleh siswa yang kemudian berpengaruh pada peningkatan prestasi belajar.

Terbukti siswa SMA Negeri 1 Prambon Nganjuk dalam mengikuti ekstrakurikuler ini dominan yang aktif dalam mengikutinya, serta banyak mendapatkan prestasi kejuaraan setiap tahunnya dari berbagai macam kegiatan ekstrakurikuler yang dilaksanakan termasuk kegiatan ekstrakurikuler keagamaan ini. Selain itu prestasi belajar yang diperoleh dari nilai raport siswa yang aktif mengikuti kegiatan ekstrakurikuler mendapat nilai yang dominan baik walaupun masih ada sedikit siswa yang masih mendapatkan nilai yang kurang baik.

Kegiatan ekstrakurikuler yang bersifat rutin (wajib) dilaksanakan pada efektif diluar jam pelajaran di dalam kelas. Seperti halnya kegiatan ekstrakurikuler keagamaan (majelis taklim) ini dilaksanakan pada sore hari jumat setelah sholat jumat dan setelah jam pelajaran selesai. Pembimbingan dan pendampingan dapat dilakukan di dalam kelas bila diperlukan. Sedangkan kegiatan ekstrakurikuler pilihan dilaksanakan diluar jam pelajaran dibina oleh praktisi, guru, dan alumni yang memiliki kualifikasi yang baik berdasarkan surat keputusan kepala sekolah.

Berdasarkan penjabaran di atas dapat disimpulkan bahwa penelitian ini dapat membuktikan teori yang sudah ada. Kegiatan ekstrakurikuler yang ada di SMA Negeri 1 Prambon Nganjuk dapat berpengaruh positif terhadap prestasi belajar siswa. Sehingga jika kegiatan ekstrakurikuler yang diiukuti siswa secara aktif dan meningkat dengan baik maka dapat diasumsikan prestasi belajar siswa dapat meningkat dengan baik juga.

\section{Pengaruh Motivasi Belajar Terhadap Prestasi Belajar Siswa di SMA Negeri 1 Prambon Nganjuk}

Penelitian ini dilakukan di SMA Negeri 1 Prambon Nganjuk yang menghasilkan hipotesis, yakni motivasi belajar berpengaruh terhadap prestasi belajar. hasil pengujian linieritas di atas, diketahui bahwa hasil perhitungan taraf signifikansi untuk variabel motivasi belajar dan prestasi belajar adalah 0,806 yang artinya (deviation from linearity) adalah $0,806>0,05$, sehingga dapat disimpulkan kedua variabel mempunyai hubungan yang linier. Nilai $0,089 X_{2}$ merupakan koefisien regresi yang menunjukkan bahwa jika nilai variabel motivasi belajar $\left(\mathrm{X}_{2}\right)$ ditingkatkan sebesar satu satuan akan menyebabkan peningkatan nilai dari variabel terikat yaitu prestasi belajar (Y) sebesar 0,089 satuan.

Variabel motivasi belajar $\left(\mathrm{X}_{2}\right)$ terhadap prestasi belajar $(\mathrm{Y})$ diketahui memiliki nilai $\mathrm{T}_{\text {hitung }}$ sebesar 2,593. Nilai $\mathrm{T}_{\text {hitung }}$ lebih besar dari $T_{\text {tabel }}$ sebesar 1,97472. Nilai signifikan yang diperoleh sebesar 0,010. Nilai signifikan ini lebih kecil dari nilai alpha 0,05 dengan demikian $\mathrm{H}_{0}$ ditolak dan $\mathrm{H}_{1}$ diterima, artinya motivasi belajar berpengaruh secara signifikan terhadap prestasi belajar siswa di SMA Negeri 1 Prambon Nganjuk. Berdasarkan hasil uji hipotesis diketahui bahwa taraf signifikan (sig) variabel motivasi belajar $\left(\mathrm{X}_{2}\right)$ adalah sebesar 0,010, kurang 
dari taraf signifikan 0,05 , maka dengan demikian $\mathrm{H}_{0}$ ditolak dan $\mathrm{H}_{1}$ diterima dan dapat disimpulan bahwa motivasi belajar berpengaruh secara parsial terhadap prestasi belajar siswa di SMA Negeri 1 Prambon Nganjuk.

Hal ini didasari pada hasil angket yang disebar kepada 165 responden, yang menjelaskan sebagian besar responden menjawab skor 3 dan 4 pada variabel penelitian yang termasuk dalam kategori sangat baik. Pada variabel motivasi belajar $\left(X_{2}\right)$ responden yang memilih skor 3 dan 4 sebanyak 89,4 \% dan variabel prestasi belajar (Y) siswa yang diperoleh dari nilai rapor siswa kelas XI. Untuk mengetahui prestasi belajar yang diperoleh siswa kelas XI dilakukan rata-rata dari nilai pengetahuan dan keterampilan siswa dari seluruh mata pelajarannya yang ditempuh.

Berdasarkan hasil perhitungan di atas, maka hasil penelitian tentang pengaruh motivasi belajar terhadap prestasi belajar ini sejalan dengan teori (Widiasworo, 19AD) dalam hal pembelajaran motivasi yang sangat diperlukan, mengikuti pembelajaran akan melahirkan aktivitas belajar yang optimal sehingga diperlukan motivasi yang tinggi oleh peserta didik. Teori tersebut terbukti bahwa setiap peserta didik harus memiliki motivasi untuk menunjang dan mendukung peserta didik tersebut dalam melakukan sesuatu dalam kegiatan belajar mengajar. Siswa SMA Negeri 1 Prambon Nganjuk dapat dibilang sudah baik dalam motivasi belajar yang dimilikinya. Dominan peserta didik yang memiliki moral tingkah laku yang disiplin dan baik, karena hal ini dipengaruhi oleh kepribadian siswa tersebut serta lingkungan keluarga dan teman sebayanya. Melalui pengaruh tersebut siswa dapat mengikuti kegiatan pembelajaran dengan baik dan memiliki motivasi belajar yang tinggi.

Sehingga hal ini sejalan dengan teori (islamuddin, 2011)yang mengemukakan bahwa macam motivasi yakni motivasi intrinsik yaitu yang berasal dari dalam individu seseorang dan motivasi ekstrinsik yaitu yang berasal dari luar individu seseorang. Adanya motivasi intrinsik merupakan motivasi yang dihasilkan dari dalam diri siswa di SMA Negeri 1 Prambon Nganjuk yang dapat dikatakan cukup baik ini terlihat dengan dimilikinya semangat yang sangat tinggi dari masing-masing kepribadian siswa untuk mengikuti kegiatan akademik maupun non akademik yang dilaksanakan di sekolah. Sehingga hal ini membuktikan bahwa siswa memiliki dan ingin mencapai suatu targetnya yang dihasilkan dalam prestasi belajar tersebut. Namun, hal ini tidak lepas juga dengan motivasi ekstrinsik yang merupakan motivasi dihasilkan dari luar diri siswa, seperti pengaruh dan dorongan lingkungan keluarga, teman sebaya, dan sebagainya. Pengaruh dan dorongan dari luar ini dapat di bilang sangat positif. Hal ini terbukti dalam lingkungan sekolah yang sangat berpengaruh positif dilihat dari guru maupun teman sebaya. Sehingga dengan adanya pengaruh positif ini, dorongan dari keluarga juga ikut andil agar anaknya dapat memilikii motivasi dan semangat yang tinggi dalam bersekolah mencapai dan meningkatkan prestasi belajarnya.

Berdasarkan penjabaran di atas dapat disimpulkan bahwa penelitian ini dapat membuktikan teori yang sudah ada. Motivasi belajar yang dimiliki siswa SMA Negeri 1 Prambon Nganjuk dapat berpengaruh positif terhadap prestasi belajar siswa. Sehingga jika motivasi belajar yang dimiliki siswa sangat tinggi maka dapat diasumsikan prestasi belajar siswa dapat meningkat dengan baik juga.

\section{Pengaruh Kegiatan Ekstrakurikuler dan Motivasi Belajar Terhadap Prestasi Belajar Siswa di SMA Negeri 1 Prambon Nganjuk}

Penelitian ini dilakukan di SMA Negeri 1 Prambon Nganjuk yang menghasilkan hipotesis, yakni kegiatan ekstrakurikuler dan motivasi belajar berpengaruh terhadap prestasi belajar siswa. guru. Hasil uji persyaratan analisis data dari uji normalitas regresi dalam penelitian ini memiliki nilai kolmogrov smirnov sebesar 1,026 dengan tingkat probabilitas lebih besar dari 0,05 yaitu sebesar 0,244. Hal tersebut menunjukkan bahwa residual model regresi berdistribusi normal. Nilai konstanta adalah 70,964. Hal ini berarti bahwa tanpa adanya pengaruh variabel bebas yaitu kegiatan ekstrakurikuler $\left(\mathrm{X}_{1}\right)$ dan motivasi belajar $\left(\mathrm{X}_{2}\right)$ maka nilai dari variabel terikat yaitu 70,964 . 
Berdasarkan hasil uji hipotesis diketahui bahwa nilai taraf signifikan (sig) variabel kegiatan ekstrakurikuler $\left(\mathrm{X}_{1}\right)$ dan motivasi belajar $\left(\mathrm{X}_{2}\right)$ adalah sebesar 0,005 kurang dari syarat taraf signifikan 0,05 , maka dengan demikian $\mathrm{H}_{0}$ ditolak dan $\mathrm{H}_{1}$ diterima dan dapat disimpulkan bahwa kegiatan ekstrakurikuler dan motivasi belajar berpengaruh secara simultan terhadap peningkatan prestasi belajar siswa di SMA Negeri 1 Prambon Nganjuk. Beserta diperkuat dari hasil koefisien determinasi bahwa diperoleh koefisien korelasi (R) sebesar 0, 252 dan koefisien determinasi ( $R$ Square) sebesar 0,064. Nilai ini menunjukkan bahwa terdapat pengaruh antara kegiatan ekstrakurikuler $\left(X_{1}\right)$ dan motivasi belajar $\left(X_{2}\right)$ yang secara bersamasama berpengaruh terhadap prestasi belajar (Y) Siswa di SMA Negeri 1 Prambon Nganjuk dan variabel tersebut bersamasama berkontribusi lebih besar terhadap prestasi belajar siswa yakni sebesar $6,4 \%$. Tabel uji $F$ secara simultan di atas, dapat diketahui nilai $F_{\text {hitung }}$ sebesar 5,493. Nilai $F_{\text {hitung }}$ ini lebih besar dari $F_{\text {tabel }}$ yaitu 3,05 . Sedangkan nilai signifikan yang diperoleh adalah sebesar 0,005 . Nilai signifikan ini lebih kecil dari nilai alpha yaitu 0,05 dengan demikian $\mathrm{H}_{0}$ ditolak dan $\mathrm{H}_{1}$ diterima, artinya kegiatan ekstrakurikuler dan motivasi belajar secara bersama-sama berpengaruh terhadap prestasi belajar siswa di SMA Negeri 1 Prambon Nganjuk.

Hal ini didasarkan pada hasil angket yang disebar kepada 165 responden, yang menjelaskan sebagian besar responden menjawab skor 3 dan 4 pada kedua variabel. Pada variabel kegiatan ekstrakurikuler $\left(X_{1}\right)$ sejumlah $91,7 \%$ dan variabel motivai belajar $\left(X_{2}\right)$ sejumlah $89,4 \%$, sedangkan variabel prestasi belajar siswa yang diperoleh dari nilai rapor siswa kelas XI. Untuk mengetahui prestasi belajar yang diperoleh siswa kelas XI dilakukan rata-rata dari nilai pengetahuan dan keterampilan siswa dari seluruh mata pelajarannya yang ditempuh. Sehingga berarti bahwa kegiatan ekstrakurikuler dan motivasi belajar mempunyai pengaruh yang sangat baik bagi seluruh siswa kelas XI dan dilaksankan dengan baik sehingga hal tersebut menambah nilai plus dalam peningkatan prestasi belajar siswa.

Hasil penelitian tersebut sejalan dengan pendapat (Djamarah, 2012)menyatakan bahwa prestasi belajar merupakan suatu kemajuan siswa dalam penilaian pendidikan tentang semua hal yang telah di tempuh di sekolah yang berhubungan dengan pengetahuan atau kecakapan atau keterampilan yang dibuktikan sesudah hasil penilaian. Adanya pernyataan tersebut terbukti bahwa dalam pembelajaran di sekolah untuk mengukur sejauh mana keberhasilan yang diperoleh siswa, dalam hal ini terlihat pada prestasi belajar yang diperolehnya selama proses kegiatan belajar mengajar di sekolah berlangsung. Sehingga dalam penelitian ini prestasi belajar tersebut dapat dilihat melalui nilai rapot yang diperoleh siswa yang didalamnya terdiri dari nilai pengetahuan dan keterampilan siswa kelas XI di SMA Negeri 1 Prambon Nganjuk.

Sejalan dengan teori yang dikemukakan oleh (Tu'u, 2004)yang berpendapat bahwa siswa dapat dikatakan berhasil dalam meraih prestasi belajar dengan memperhatikan faktor-faktor yang dapat mempengaruhinya yakni tingkat dari kecerdasan anak yang baik, mempunyai bakat yang sesuai dengan pelajaran, adanya perhatian dan juga minat pembelajaran yang tinggi, motivasi belajar yang baik, cara baik untuk belajar dan strategi pembelajaran yang dikembangkan oleh guru. Mendorong anak untuk maju melalui suasana keluarga, serta keadaan lingkungan di sekolah yang teratur, disiplin dan tertib termasuk pendorong proses untuk mencapai prestasi belajar. Sesuai dengan teori tersebut bahwa terdapat beberapa faktor yang mempengaruhi keberhasilan siswa dalam meraih prestasi belajarnya. Adanya bakat yang sesuai dengan pelajaran yang dapat diartikan dengan mengikuti kegiatan ekstrakurikuler yang dilaksanakan di sekolah tersebut. Karena dengan mengikuti kegiatan ekstrakurikuler dapat mengasah dan mengembangkan bakat dan minat siswa tersebut sehingga akan membawa dampak positif dalam pembelajaran di sekolah dan siswa tersebut. Kemudian adanya motivasi belajar yang baik dari siswa tersebut (intrinsik) maupun dari luar (ekstrinsik).

Penjelasan di atas diperkuat oleh pendapat (slameto, 2010)yang mengemukakan terdapat dua faktor yang dapat mempengaruhi prestasi belajar, yakni faktor intern dan faktor ekstern. Faktor intern berupa faktor jasmaniah, faktor psikologis, 
dan faktor kelelahan. Faktor ekstern berupa faktor keluarga, faktor sekolah, dan faktor masyarakat. Salah satu faktor tersebut adalah faktor internal yakni faktor yang berasal dari dalam individu peserta didik yakni faktor psikologis, yang berupa faktor bakat yang dimiliki peserta didik atau siswa yang dapat dikembangkan melalui kegiatan ekstrakurikuler dan menunjang kegiatan belajar mengajar di sekolah. Selain faktor internal mengenai faktor psikologis yang berupa faktor bakat, motivasi belajar juga dapat berpengaruh pada prestasi belajar. Motivasi belajar termasuk dalam faktor psikologis yang berupa motif atau dorongan yang dari dalam individu peserta didik untuk melakukan sesuatu dalam mencapai kegiatan yang dilakukan.

Berdasarkan penjabaran di atas dapat disimpulkan bahwa penelitian ini dapat membuktikan teori yang sudah ada. Kegiatan ekstrakurikuler dan motivasi belajar di SMA Negeri 1 Prambon Nganjuk dapat mempengaruhi prestasi belajar yang diperoleh siswa. Adanya kegiatan ekstrakurikuler dan motivasi belajar memberikan dukungan, dorongan, dan kontribusi yang positif terhadap prestasi belajar siswa yang tinggi dan optimal di SMA Negeri 1 Prambon Nganjuk.

\section{KESIMPULAN}

Berdasarkan hasil penelitian yang telah dipaparkan dapat diambil kesimpulan sebagai berikut: 1) Berdasarkan hasil analisis data yang diperoleh pada variabel kegiatan ekstrakurikuler $\left(X_{1}\right)$ nilai $T_{\text {hitung }}$ sebesar 2,339. Nilai signifikan variabel kegiatan ekstrakurikuler terhadap prestasi belajar sebesar 0,021 nilai tersebut lebih kecil dari nilai alpha 0,05 dengan demikian $\mathrm{H}_{0}$ ditolak dan $\mathrm{H}_{1}$ diterima, artinya kegiatan ekstrakurikuler berpengaruh secara signifikan terhadap prestasi belajar siswa di SMA Negeri 1 Prambon Nganjuk. 2) Berdasarkan hasil analisis data yang diperoleh pada variabel motivasi belajar $\left(X_{2}\right)$ nilai $T_{\text {hitung }}$ sebesar 2,593. Nilai signifikan variabel motivasi belajar tehadap prestasi belajar sebesar 0,010 nilai tersebut lebih kecil dari jilai alpha 0,05 dengan demikian $\mathrm{H}_{0}$ ditolak dan $\mathrm{H}_{1}$ diterima, artinya motivasi belajar berpengaruh secara signifikan terhadap prestasi belajar siswa di SMA
Negeri 1 Prambon Nganjuk. 3) Berdasarkan hasil data pada uji $\mathrm{F}$ menunjukkan nilai $\mathrm{F}_{\text {hitung }}$ sebesar 5,493. Nilai signifikan variabel kegiatan ekstrakurikuler dan motivasi belajar terhadap prestasi belajar yang diperoleh adalah sebesar 0,005 . Nilai signifikan ini lebih kecil dari nilai alpha yaitu 0,05 dengan demikian $\mathrm{H}_{0}$ ditolak dan $\mathrm{H}_{1}$ diterima, artinya kegiatan ekstrakurikuler dan motivasi belajar secara bersama-sama berpengaruh terhadap prestasi belajar siswa di SMA Negeri 1 Prambon Nganjuk. Adapun besarnya pengaruh kegiatan ekstrakurikuler dan motivasi belajar terhadap prestasi belajar siswa yaitu sebesar $6,4 \%$.

\section{SARAN}

Berdasarkan hasil dan kesimpulan, maka saran diberikan kepada pihak-pihak terkait yakni: 1) Bagi kepala sekolah, diharapkan lebih memperhatikan dan memberikan dorongan terhadap siswa untuk terus aktif dalam kegiatan akademik maupun non akademik siswa seperti halnya kegiatan ekstrakurikuler ini, serta terus memberikan motivasi terhadap siswa untuk lebih semangat dalam mengikuti kegiatan belajar mengajar di sekolah, sehingga siswa dapat mengoptimalkan kemampuannya dalam prestasi belajar yang lebih baik. 2) Bagi pembina ekstrakurikuler maupun guru mata pelajaran sangat berperan penting dalam membina dan mengembangkan potensi siswa. Oleh karena itu, seorang guru harus mengetahui kendala-kendala siswa yang kurang aktif dalam kegiatan ekstrakurikuler maupun kegiatan belajar mengajar di kelas. Dengan mengarahkan siswa dalam hal memanajemen waktu dengan sebaikbaiknya dan bagaimana cara siswa dapat belajar lebih efektif. 3) Bagi siswa, siswasiswi dapat memaksimalkan dan memanfaatkan kegiatan yang ada di sekolah. Seperti halnya kegiatan ekstrakurikuler ini di dilaksanakan untuk dapat diikuti siswa, dengan tujuan dapat mengasah bakat, minat, dan kemmpuannya dalam suatu bidang kegiatan ekstrakurikuler. Selain motivasi positif dari luar, siswa harus dapat memotivasi diri sendiri dalam menentukan target prestasi belajar yang ingin di capainya. 4) Bagi peneliti lain, diharapkan untuk melakukan penelitian mengenai faktor yang mempengaruhi 
prestasi belajar dan menambah variabel bebas lainnya sehingga membantu untuk meningkatkan prestasi belajar siswa. Seperti variabel yang tidak diajukan dalam penelitian ini, peneliti menemukan variabel lain pada saat penelitian di lapangan yang dapat mempengaruhi prestasi belajar, diantaranya: pengaruh teman, minat siswa, disiplin belajar, dan kebiasaan belajar. Selain variabel independen di atas peneliti lain dapat mencari variabel-variabel lain yang dapat mempengaruhi prestasi belajar siswa dan teori terbaru agar terlaksana penelitian yang akan diteliti.

\section{DAFTAR RUJUKAN}

Ahmadi, Abu \& Supriyono, Widodo. (2004). Psikologi Belajar. Jakarta:PT Rineka Cipta.

Arumsari, Dian. (2017). Pengaruh Media Pembelajaran dan Keterampilan Pengelolaan Kelas Terhadap Prestasi Belajar Siswa SMK Negeri 5 Madiun, Jurnal Akuntansi dan Pendidikan, Vol. 6 (1) hal 13-25.

Emda, Amna. (2017). Kedudukan Motivasi Belajar Siswa dalam Pembelajaran, Lantanida Journal, Vol 5 (2) hal. 93-196.

Djamarah, Syaiful Bahri. (2012). Prestasi Belajar dan Kompetensi Guru. Surabaya: Usaha Nasional.

Islamuddin, Haryu. (2011). Psikologi Pendidikan. Jember: STAIN Jember Press.

Lestari, Ria Yuni, (2016). Peran Kegiatan Ekstrakurikuler Dalam Mengembangkan Watak Kewarganegaraan Peserta Didik, Jurnal Untirta, Vol. 1 (2) hal. 136-152.

Makmun, Abin Syamsuddin. (2007). Psikologi Kependidikan. Bandung: PT Rosda Karya Remaja.

Monicca, dkk. (2015). Pengaruh Minat Belajar, Motivasi Belajar Dan Prestasi Belajar Matematika Terhadap Prestasi Belajar Akuntansi Siswa Kelas $\mathrm{X}$ Jurusan Akuntansi di Smk Palebon
Semarang, Jurnal Unnes, Vol. 4 (3) hal. 414-426.

Nuryanto, Slamet. (2017). Manajemen Kegiatan Ekstrakurikuler di SD Al Irsyad 01 Purwokerto, Jurnal Kependidikan, Vol 5 (1) hal 115-129.

Peraturan Menteri Pendidikan dan Kebudayaan Republik Indonesia Nomor 62 tahun 2014 Tentang Kegiatan Ekstrakurikuler pada Pendidikan Dasar dan Menengah. http://www.dikdas.kemendikbud.go.id.

Prawira, Purwa Atmaja. (2012). Psikologi Pendidikan dalam Perspektif Baru. Jogjakarta: Ar-Ruzz Media.

Prihatin, Eka. (2011). Manajemen Peserta Didik. Bandung: Alfabeta.

Rozaini, Noni \& Anti, Sandra Dewi. (2017). Pengaruh Motivasi Belajar dan Kepercayaan Diri Siswa Terhadap Prestasi Belajar, Jurnal Niagawan, Vol 6 (2) hal. 1-6.

Siberman, Melvin L. (2016). Active Learning 101 Cara Belajar Siswa Aktif. Bandung: Penerbit Nuansa.

Sidik, Zafar \& Soebandi, (2018). Upaya meningkatkan motivasi belajar siswa melalui kemampuan komunikasi interpersonal guru, Jurnal Pendidikan Manajemen Perkantoran, Vol. 2 No. 1.

Slameto. (2010). Belajar dan Faktor-faktor yang Mempengaruhinya. Jakarta:Bumi Aksara.

Sugiyono. (2017). Metodologi Penelitian Pendidikan Kuantitatif, Kualitatif, dan $R \& D$. Bandung. Alfabeta

Tu'u, Tulus. (2004). Peran Disiplin pada Perilaku dan Prestasi Belajar. Jakarta: Grasindo.

Widiasworo, Erwin. (2015). 19 Kiat Sukses Membangkitkan Motivasi Belajar Peserta Didik. Jogjakarta: Ar-Ruzz Media.

Winkel. (2004). Psikologi Pengajaran. Yogyakarta: Media Abadi. 